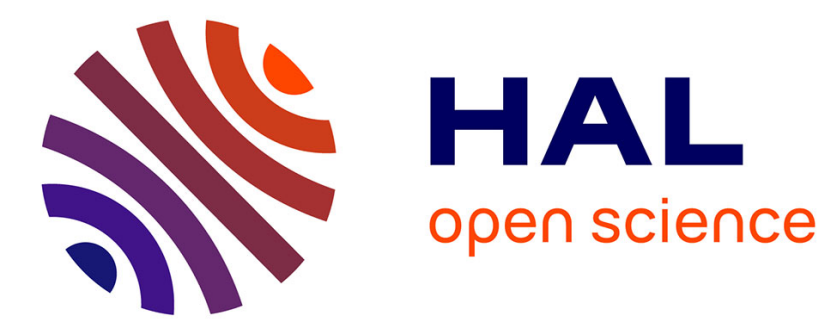

\title{
THE IMPACT OF BRAND FAMILIARITY, BRANDING AND DISTRIBUTION STRATEGY ON LUXURY BRAND DILUTION
}

F. Magnoni, E. Roux

\section{- To cite this version:}

F. Magnoni, E. Roux. THE IMPACT OF BRAND FAMILIARITY, BRANDING AND DISTRIBUTION STRATEGY ON LUXURY BRAND DILUTION. 2011, 4 p. halshs-00644893

\section{HAL Id: halshs-00644893 \\ https://shs.hal.science/halshs-00644893}

Submitted on 25 Nov 2011

HAL is a multi-disciplinary open access archive for the deposit and dissemination of scientific research documents, whether they are published or not. The documents may come from teaching and research institutions in France or abroad, or from public or private research centers.
L'archive ouverte pluridisciplinaire HAL, est destinée au dépôt et à la diffusion de documents scientifiques de niveau recherche, publiés ou non, émanant des établissements d'enseignement et de recherche français ou étrangers, des laboratoires publics ou privés. 


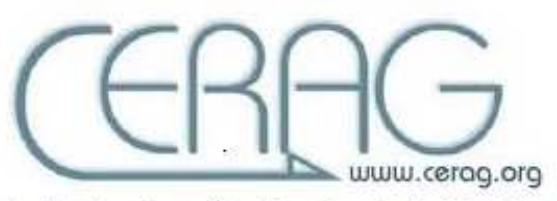

Centre d'Etudes et de Recherches Appliquées à la Gestion_U.M.R. CN.R.S. 5820

CAHIER DE RECHERCHE $n^{\circ} 2011-05$ E3

THE IMPACT OF BRAND FAMILIARITY, BRANDING AND DISTRIBUTION STRATEGY ON LUXURY BRAND DILUTION

Fanny Magnoni

Laboratoire CERAG UMR CNRS 5820

IAE Grenoble,

Pierre Mendès France University, France

Elyette Roux

$$
\text { CERGAM }
$$

IAE Aix-en-Provence,

Aix-Marseille University, France

Unité Mixte de Recherche CNRS / Université Pierre Mendès France Grenoble 2

Tél. : 0476635381 Fax : 0476546068

Sciences sociales \& humaines 


\title{
THE IMPACT OF BRAND FAMILIARITY, BRANDING AND DISTRIBUTION STRATEGY ON LUXURY BRAND DILUTION
}

\author{
Fanny Magnoni, Cerag IAE Grenoble, Pierre Mendès France University, France \\ Elyette Roux, Cergam IAE Aix-en-Provence, Aix-Marseille University, France
}

\section{INTRODUCTION}

From the consumer point of view, step-down line extension is the launch of a new product, which is perceived as lower quality than the other products a brand currently sells, in the category of the pre-existing brand (Magnoni and Roux, 2008). Although step-down line extension is not a new business practice, it has greatly increased in recent years to meet new market trends. Today, the purchasing power crisis and the democratization of the luxury sector attract more price-sensitive customers with lower-end products (Lipovetsky and Roux, 2003; Kapferer and Bastien, 2008). Analysts have even invented a new category called Masstige, which stresses that the prestige brand targets a mass market (Silverstein and Fiske, 2003; Danziger, 2005). Accordingly, more and more fashion designers are launching lines, between 30 and $50 \%$ cheaper than the original lines, under their brand names. Ralph Lauren's downward stretch from the exclusive "Purple Label" to the casual "Polo line" is a good example of this phenomenon. Likewise, Armani has six different lines that range from his couture collection, "Giorgio Armani-Privé", to the everyday sportswear line, "Armani jeans" and even "Armani Exchange" in some foreign markets. If Saint Laurent was a pioneer with Saint Laurent Rive Gauche, then today fashion designers are increasingly stretching their brands down (e.g., Galliano by John Galliano, Paul \& Joe Sister, Marc by Marc Jacobs, See by Chloé). Although step-down line extensions can use brand equity to increase the brand's sales, it may also be a dangerous strategy (Aaker, 1997) that dilutes brand equity, especially for luxury brands (Kim and Lavack, 1996; Kirmani, Sood and Bridges, 1999; Kim, Lavack and Smith, 2001). In comparison to brand extension, step-down line extension is a new research area where studies are relatively limited (Randall, Ulrich and Reibstein 1998; Tafani Michel and Rosa 2009; Hamilton and Chernev, 2010; Jevons and Pontes, 2010). Little is known about the feedback effects of this strategy on core brand equity from a consumer's perspective. This article aims to evaluate the impact of a luxury brand's step-down line extension on consumer attitudes toward the core brand, taking into account brand familiarity, branding and distribution strategy as explanatory variables for the possible dilution effects.

\section{THEORETICAL FRAMEWORK AND RESEARCH HYPOTHESES}

\section{Impact of a luxury brand's step-down line extension on attitudes to the core brand}

We refer to categorization theory (Rosch and Mervis, 1975) and the models of schema change (Weber and Crocker, 1983) to explain the impact of the step-down line extension of a luxury brand on attitudes toward the core brand. According to this framework, a brand is a schema (a cognitive category) that gathers the individual's knowledge of the brand. Categorization and schema theories can explain the core brand dilution that brand extensions cause (Loken and Roedder-John, 1993; Milberg, Park and McCarthy, 1997; Gürhan-Canli and Maheswaran, 1998). Brand dilution refers to the negative feedback-effects on the core brand beliefs and attitudes. Both theories agree that the perceived consistency between the extension and the core brand influences attitude changes in response to brand extensions and that these changes follow a process of assimilation and accommodation (Park McCarthy and Milberg, 1993). Assimilation occurs when the brand extension is relatively consistent with the core brand and, therefore, does not affect it. On the other hand, accommodation occurs when the brand extension is not consistent with the core brand and, therefore, modifies attitudes towards it. Two models, which have received support in brand extension research, can explain this modification of the existing schema: the sub-typing model and the bookkeeping model (Weber and Crocker, 1983). The sub-typing model suggests that an inconsistent extension is stored in a different schema, which explains why an inconsistent extension does not affect the core brand and its original products. In contrast, the bookkeeping model proposes that an inconsistent extension is integrated into the existing schema (i.e., the core brand) and alters it. The 
consumer analyzes all information about the extension, and the more inconsistent the extension is with the core brand, the more the core brand is modified.

Luxury brands exhibit an international awareness that incorporates, at the supply level, expertise in applied art and human involvement in the creative process and that is characterized, at the demand level, by products or services that surpass function to meet aesthetic needs. Luxury brands are located at the top of the price pyramid with prices that exceed those of products and brands with comparable practical functions (McKinsey, 1990). The differential dimensions of luxury brands include traditional or creative heritage, exclusivity or selectivity, excellent quality, high prices, hedonistic functions, and conspicuous consumption (Garfein, 1989; Roux, 1991; Dubois, Laurent and Czellar, 2001; Lipovetsky and Roux, 2003; Wiedmann, Hennings and Siebels, 2009). The step-down line extension of a luxury brand, which associates it with lower quality and more affordable prices, can therefore damage the core brand (Keller, 1993). According to the bookkeeping model, the decreased quality of the step-down line extension appears as inconsistent information and leads the consumer to revalue the core brand at a lower level (Milberg, Park and McCarthy, 1997). In line with Kirmani, Sood and Bridges (1999), we suggest that the step-down line extension of a luxury brand will damage core brand evaluation (i.e., the affective component of the brand attitude) and propose the following hypothesis:

H1: The step-down line extension of a luxury brand has a negative influence on core brand evaluation. Moreover, consumers perceive the original products as lower quality when a step-down line extension is launched (Wernerfelt, 1988). Flawed quality in a product from the brand line can negatively affect sales of the brand (Sullivan, 1990). In addition, Kim, Lavack and Smith (2001) showed that core brand evaluation (especially measured by purchase intention) decreases after step-down line extension. Thus, we expect that the step-down line extension of a luxury brand will damage consumer purchasing intentions toward brand products (i.e., the conative component of the brand attitude). Hypothesis $\mathrm{H} 2$ is as follows:

H2: The step-down line extension of a luxury brand has a negative influence on core brand purchasing intention.

\section{The determinants of the impact of a luxury brand's step-down line extension on core brand attitude}

The branding strategy of a step-down line extension (i.e., the brand name of the extension) and its distribution channel are two strategic factors that can minimize dilution effects (Kirmani, Sood and Bridges, 1999; Olavarrieta et al., 2009). Brand extension studies refer to the sub-typing model to understand how the brand name of an extension influences dilution effects (Milberg, Park and McCarthy, 1997). In contrast to an extension that uses only the existing core brand name, a sub-brand strategy (e.g., Armani Exchange and Courtyard by Marriott) helps the consumer to dissociate the extension from the core brand. Consequently, the consumer considers the extension a sub-type, which will be stored in a distinct schema. Therefore, this separation limits dilution effects. In line with the sub-typing model, we propose that the deterioration of core brand attitude will be stronger when the step-down line extension adopts the existing brand name rather than a sub-brand name. Although, to our knowledge, the influence of distribution channels has not been tested, we can use the subtyping model to propose that stronger dilution effects appear when the step-down line extension is sold in the existing distribution channel rather than a separate channel. Thus, we propose hypotheses H3a, H3b, H4a and H4b:

H3: When the step-down line extension uses the existing brand name, there is a stronger decrease in (H3a) core brand evaluation and (H3b) core brand purchasing intention than when the step-down line extension uses a sub-brand name.

H4: When the step-down line extension is sold through the existing distribution channel, there is a stronger decrease in ( $\mathrm{H} 4 \mathrm{a})$ core brand evaluation and $(\mathrm{H} 4 \mathrm{~b})$ core brand purchasing intention than when the stepdown line extension is not sold in the existing distribution channel.

One individual variable is also relevant to our study: brand familiarity. Brand familiarity corresponds to the number of brand-related experiences. The influence of brand familiarity has been investigated in brand extension research (Sheinin, 2000; Martinez and de Chernatony, 2004; Thorbjørnsen, 2005). Both of the schema change models can predict the role of brand familiarity in dilution effects (Thorbjørnsen, 2005). When brand familiarity is low, the information about brand extension is stored in a different schema that does not affect the core brand (i.e., a sub-typing model). However, when brand familiarity is high, the consumer carefully analyzes the information about brand extension. When this information is integrated into the existing schema, it changes the schema (i.e., the bookkeeping model). A consumer's objective familiarity with the brand (i.e., the fact of being a customer or not) also affects the dilution effects. Kirmani, Sood and Bridges (1999) found that, after a step-down line extension, the brand owners' attitudes decreased more than the non-owners' attitudes. Finally, we propose hypotheses $\mathrm{H} 5 \mathrm{a}$ and $\mathrm{H} 5 \mathrm{~b}$ :

H5: When the consumer is a customer of the brand, a step-down line extension causes a stronger decrease in (H5a) core brand evaluation and (H5b) core brand purchasing intention than when the consumer is not a brand customer. 


\section{METHODOLOGY}

\section{Product categories, selected brand and step-down line extension}

We selected the Armani brand after a pre-test with 30 respondents to verify its prestige orientation. We rated the prestige orientation of the brand on a seven-point Likert scale that investigated the importance of the characteristics luxury and status to the consumer when he purchases the brand (Park, McCarthy and Milberg, 1993). As expected, we found that the mean of prestige orientation for the Armani brand was high (5.73). Armani also presents the advantage of studying a real step-down line extension that has been distributed abroad, but not in France: the Armani Exchange line. This line is the most affordable Armani line and is about 50\% cheaper than the Armani Jeans line. We used four products (dress, top, jean and shirt) and created ads from real advertising visuals and Armani Exchange slogans to expose the respondents to stimuli that are close to market conditions. The perceived quality of a product depends on both its perceived price and the consumer's information about its attributes (Chang and Wildt, 1994; Monroe, 1990; Zeithaml, 1988). Therefore, we mentioned both the real prices of the products, to indicate quality, and information on their physical attributes (e.g., wool, silk, hand-washing or washing machine). To manipulate both modalities of the extension branding strategy (i.e., existing brand name vs. sub-brand), we clearly mentioned that the products were sold either under the existing brand name Giorgio Armani or under the sub-brand Armani Exchange. To manipulate the two modalities of the extension distribution channel, we presented the products as distributed either in Armani stores and luxury fashion brand stores (i.e., the existing channel) or in specialized stores Armani Exchange (i.e., a distinct channel). We verified manipulation success with a qualitative study with 25 respondents, as advised by Perdue and Summers (1986).

\section{Sample and data collection}

We differentiated customers from non-customers to study the influence of objective familiarity with the brand. We selected customer respondents just after their visits to the stores that distribute the brand and through a "snowball" sampling process. The non-customers were university students who agreed to participate in the study outside their classes. It should be noted that students are a potential target for the Armani Exchange line in the countries where it is sold. We used two filter questions to select only respondents who perceived a decrease in terms of quality and did not know the line Armani Exchange. The final sample was composed of 200 respondents who were equally distributed between both modalities of the two factors; branding strategy and distribution channel. The sample was mixed (52.5\% men and 44.5\% women) and relatively young (83\% were under the age of 35). We used the before-and-after pseudo-experimental method to observe individual changes. We created a questionnaire in two parts, and, to avoid a test effect, we administered it with a one-week gap between the first and the second parts. Each respondent had only one treatment, an ad announcing the launch of the step-down extension, which we presented at the beginning of the second part.

\section{Measurement of variables}

We measured one item that is related to a general opinion of the brand on a seven-point differential semantic scale to operationalize core brand evaluation (i.e., the affective component of attitude). We chose an item that evaluates the opportunity of purchasing the brand on a seven-point Likert scale to measure the purchasing intention of the brand. These two items were measured before and after the respondents were exposed to the step-down line extension ad. We used the difference between these before and after scores to operationalize the evolution of the two components of brand attitude. Two "yes/no" items measure a respondent's objective familiarity with the brand. According to Alba and Hutchinson's (1987) definition, the first item targets the ownership of brand products, and the second targets the purchasing of brand products.

\section{RESULTS}

\section{Impact of a luxury brand's step-down line extension on core brand attitude}

We computed a Multivariate Analysis of Variance (MANOVA) for repeated measures to evaluate the impact of the step-down line extension on the two components of core brand attitude. We introduced two between-subjects factors into the analysis, treatment (i.e., a nominal variable with four modalities) and objective familiarity with the brand (i.e., customer $v s$. non-customer), to check the stability of the results. The results indicate that the effect of step-down line extension is significant $(\mathrm{F}=72,108 ; p=0.000)$, regardless of the statistic that is used. Step-down line extension did not have a significant interaction with the treatment $(\mathrm{F}<2.63 ; p>0.05)$, but it did 
have a significant interaction with familiarity $(\mathrm{F}=11.943 ; p=0.000)$, which indicates that familiarity influences the effect of step-down line extension.

As we expected, step-down line extension damages the affective component of core brand attitude. It had a significant negative impact on core brand evaluation $\left(\mathrm{BEV}_{\text {before }}=5.40 ; \mathrm{BEV}_{\text {after }}=4.38 ; \mathrm{F}=121.588 ; p=0.000\right)$ and explained $38.8 \%$ of the variance of evaluation. This result supports $\mathbf{H 1}$.

On the other hand, step-down line extension does not weaken the conative component of core brand attitude. It had no significant effect on the purchasing intention of the core brand (BPI ${ }_{\text {before }}=3.92 ; \mathrm{BPI}_{\text {after }}=4.09 ; \mathrm{F}=$ 1.778; $p>0.05$ ). On the contrary, purchasing intention tended to increase after the extension. Hypothesis $\mathbf{H} 2$ is therefore not supported. To better understand this result, we studied the estimated marginal means of the purchasing intention before and after the extension according to objective familiarity and conducted paired sample $t$-tests. Purchasing intention significantly decreased for customers ( $\mathrm{PI}$ before $=4.49 ; \mathrm{PI}_{\text {after }}=4.18, \mathrm{t}=$ 2.002; $p<0.05$ ), but it significantly increased for non-customers ( $\mathrm{PI}$ before $=3.35 ; \mathrm{PI}_{\text {after }}=4.00 ; \mathrm{t}=-3.199 ; p<$ 0.05). Therefore, our results did not support hypothesis $\mathrm{H} 2$ because of a "cancellation" effect, which might be attributable to the use of a student population in the study. As we noted above, the Armani Exchange line targets students as potential customers. If students know that Armani is launching a cheaper line, they might be more inclined to buy the brand's clothes, which have become more affordable for them. These conclusions support Huvé-Nabec and Fontaine's (2003) findings on the distribution channel extension of a selective brand.

\section{Determinants of the impact of a luxury brand's step-down line extension on core brand attitude}

We examined hypotheses H3a-H5b with a 2x2x2 MANOVA (between-subjects) with two dependant variables (evolution of evaluation and evolution of purchasing intention). The between-subjects factors were branding strategy (i.e., existing brand name vs. sub-brand), distribution channel (i.e., existing channel $v s$. distinct channel) and objective familiarity with the brand (i.e., customer $v s$. non-customer).

The branding strategy of step-down line extension had no significant effect on the core brand evaluation $(\mathrm{F}=$ $0.037 ; p>0.05)$ and the core brand purchasing intention $(\mathrm{F}=0.221 ; p>0.05)$. Contrary to the findings of several brand extension studies, our results did not find the "isolating" effect of sub-brand strategy. These findings do not support Hypotheses H3a and H3b. However, our results did confirm our expectations for core brand evaluation; it decreases slightly when the extension is launched under the existing brand name $(\Delta$ existing brand name $\left.=-1.034 ; \Delta_{\text {sub-brand }}=-0.999\right)$.

Likewise, there was no significant influence for the distribution channel of the step-down line extension (core brand evaluation: $\mathrm{F}=2.008 ; p>0.05$; core brand purchasing intention: $\mathrm{F}=0.055 ; p>0.05$ ). In other words, the impact of the extension on core brand attitude does not vary with the distribution channel of the step-down extension. Hypotheses H4a and H4b are therefore not supported. Although these two strategic factors (branding strategy and distribution channel) had no direct influence, we nevertheless noticed significant interaction effects in the two components of core brand attitude.

Finally, a consumer's objective familiarity with the brand (customer $v s$. non-customer) had a negative influence on the two components of attitude: core brand evaluation $(\mathrm{F}=16.935 ; p=0.000)$ and core brand purchasing intention $(\mathrm{F}=14.173 ; p=0.000)$. The estimated marginal means showed a stronger deterioration with customers than with non-customers for both components: core brand evaluation $\left(\Delta_{\text {clients }}=-1.396 ; \Delta_{\text {non-clients }}=-0.637\right)$ and core brand purchasing intention $\left(\Delta_{\text {clients }}=-0.310 ; \Delta_{\text {non-clients }}=0.650\right)$. These findings support hypotheses H5a and H5b.

\section{DISCUSSION AND CONCLUSION}

This research provides a better understanding of the feedback effects of the step-down line extension of a luxury brand on core brand attitudes. These findings suggest that the affective component of attitude (brand evaluation) deteriorates regardless of the consumer's level of brand familiarity but that the conative component (brand purchasing intention) decreases for customers and increases for non-customers. Our research also assessed the influence of the branding strategy that the step-down line extension adopts, but we did not find the isolating effect of a sub-branding strategy. This result is important because managers often use sub-brands to stretch down their brands. Nevertheless, our study identifies the interaction effects between two strategic factors, branding strategy and distribution channel. A core brand attitude is most damaged when a step-down line extension is launched under the existing brand name and sold in the brand's existing distribution channel. Finally, our research proposes new insights on the role of brand familiarity. Like Kirmani, Sood and Bridges (1999), our research shows that core brand dilution depends on the level of a consumer's objective familiarity with the brand.

However, our research is subject to some limitations. We created ads from actual information elements to expose the respondents to stimuli that approximated market conditions. Although we carefully checked the external variables related to the ad, we cannot ignore the possibility that these documents might have influenced answers. 
Moreover, clothes are products whose use is "public". Thus, it would be useful to investigate the feedback effects of step-down line extension when the products of luxury brands are used in "private" situations (e.g., underwear, body care and skin care products) or in the service sector (e.g., luxury hotels, restaurants and credit cards such as American Express). A brand's vertical range (i.e., the different quality levels it covers) and the number of product categories it occupies could also affect the effects of dilution. Therefore, future studies could compare the feedback effects for brands that have never launched step-down line extensions (e.g., Gucci) with brands that are vertically extended (e.g., Armani). Finally, other explanatory variables need to be investigated. For example, Buil, De Chernatony and Hem (2009) show that feedback effects of brand extensions on core brand equity differ across countries. Thus, it would be interesting to analyze the influence of culture in vertical line extension research.

Full references available upon request 